\title{
Identifying the resource conditions that maximize the relationship between ambidexterity and new product performance
}

\begin{tabular}{|r|l|}
\hline Journal: & Journal of Business and Industrial Marketing \\
\hline Manuscript ID & JBIM-08-2016-0191.R2 \\
\hline Manuscript Type: & Original Article \\
\hline Keywords: & $\begin{array}{l}\text { new product performance, exploratory product innovation, exploitative } \\
\text { product performance, slack resources, social networking capability, } \\
\text { ambidexterity }\end{array}$ \\
\hline \multicolumn{2}{|l}{} \\
\hline
\end{tabular}

SCHOLARONE $^{\text {Ix }}$

Manuscripts 


\section{Identifying the resource conditions that maximize the relationship between ambidexterity and new product performance}

\section{Introduction}

Emerging economies are undergoing transition toward market-based systems and rapid economic development (Mellahi et al., 2011). The long-term viability of firms operating in emerging economies depends on how well they embody product innovation in their efforts to enhance their competitiveness (Zhang and $\mathrm{Wu}, 2013$ ). Two types of product innovation have been identified in the literature - exploratory product innovation, reflecting the firm's capacity to generate new processes directed toward the development of a new product, and exploitative product innovation, reflecting the firm's capacity to refine existing processes directed toward the development of new products (Gupta et al., 2006; O'Cass et al., 2014).

Pursuing market opportunities through exploitative and exploratory product innovation places significant pressure on firms and creates a key strategic dilemma. While exploring new product development to keep up with changes in customers' needs offers longterm success, an overemphasis on exploration can lead to failure trap (an inability to exploit the benefits of successful innovations) (Gupta et al., 2006). Similarly, while exploiting existing product development offers short-term success, an overemphasis on exploitation may lead to core-rigidity (an inability to adapt to emerging market changes) and can become an impediment to long-term viability (Atuahene-Gima, 2005).

Given the distinct nature and focus of exploitative and exploratory product innovation, many suggest that the synchronous pursuit of these activities is hard to manage (Voss and Voss, 2013). It is suggested that firms can manage ambidexterity through pursuing a complementarity between different levels of exploration and exploitation [hereafter 'combined dimension of ambidexterity' (CD)] or a balance between symmetrical levels of 
exploration and exploitation [hereafter 'balanced dimension of ambidexterity' (BD)] to enhance the success of new products (He and Wong, 2004). Yet, prior literature lacks clarity in regards to the conditions under which firms with different levels of resources should pursue BD or CD (Wei et al., 2014). The failure to demonstrate the conditions under which the pursuit of $\mathrm{CD}$ or $\mathrm{BD}$ is most effective poses a serious challenge for firms in emerging economies. Firms in emerging economies face resource constraints related to investing in new product development in terms of financial assets, expertise of employees, and advanced technologies, compared to firms in advanced economies (e.g., Subramaniam et al., 2015). This places the issue of resource availability as a priority for firms operating in emerging economies.

This study aims to identify the resource conditions that help maximize the effect of $\mathrm{BD}$ versus $\mathrm{CD}$ on new product performance (hereafter NPP) in emerging economies. Our study provides two contributions. First, we demonstrate the conditions under which firms in emerging economies should pursue BD or CD to drive NPP. NPP refers to the market success of a firm's new products. Although previous research investigates the effect of ambidexterity on firm performance, little attention is given to the resource conditions under which pursuing BD or CD within a new product development project helps firms to achieve NPP. Understanding the contingent value of $\mathrm{BD}$ and $\mathrm{CD}$ is essential for new product development because firms that fail to invest adequate resources (e.g., funds, employees) in a new product development project may impair its ability to simultaneously pursue both exploratory and exploitative product innovation.

Second, we demonstrate the role of discretionary slack and social networking capability in facilitating CD and BD's effect on NPP. The work of Cao et al. (2009) contributes significantly to understanding of the contingent value of $\mathrm{CD}$ and $\mathrm{BD}$ with respect to the firm's profitability, taking into account of the quantity of resources firm possess 
(indicated by firm size) and firms can access externally (through environmental munificence). Yet, their work raises two issues. First, the use of firm size to signify the level of available resources is not without problems. There is evidence that firm size represented by the number of employees does not account for whether a firm has a larger or smaller market size and corresponding financial assets (Katila and Shane, 2005). Departing from this approach, we specifically investigate the contingent outcomes of BD and CD with respect to NPP based on the level of discretionary slack resources. Prior studies (e.g., Troilo et al., 2014) support the contention that discretionary slack resources enable firms to make flexible managerial decisions and engage in radical innovation where outcomes are more uncertain in competitive markets. We focus on slack resources as representing available resources in excess of the minimum necessary level to produce a given output (Troilo et al., 2014).

Second, the use of environmental munificence to signify the firm's ability to access external resources is also not without problems. Cao et al. (2009) operationalize environmental munificence as "the average sales growth of firms in the same industry" (p. 789). However, when average sales growth is high it does not necessarily mean firms can access external resources that belong to other firms, if they do not have good relationships with those firms. Hence, we investigate the contingent outcomes of BD and CD with respect to NPP based on the firm's social networking capability. Social networking capability has received increasing attention as a mechanism that enables firms in emerging economies to acquire the external resources and institutional support required for new product development through building managerial ties with partners such as other firms and political officials (Zhang and $\mathrm{Wu}, 2013$ ). Our focus responds to the call by scholars (Sheng et al., 2011) for more work on the role of managerial ties in emerging economies, where social networking capability may help firms overcome resource constraints. 


\section{Literature Review}

Researchers refer to ambidexterity as a firm's ability to pursue two distinct activities, namely exploration and exploitation (Lubatkin et al., 2006; Eltantawy, 2016). Exploration represents the behaviors characterized by experimentation, discovery, search, and innovation, while exploitation denotes behaviors characterized by efficiency, refinement, production and implementation (March, 1991). Given the inherent differences between exploration and exploitation, pursuing ambidexterity may increase tensions and conflict among employees and result in negative outcomes (Gupta et al., 2006).

Ambidexterity researchers have recently advanced different theoretical perspectives for managing the tension between exploration and exploitation including structural, contextual, and realized perspectives (Simsek, 2009). Those advancing the structural and contextual perspectives adopt the view that ambidexterity is best managed through structural differentiation and/or building a contextual system that allows a firm to be able to engage in exploration and exploitation simultaneously (Simsek, 2009). While the structural and contextual perspectives place emphasis on the antecedents of ambidexterity, the realized perspective emphasizes the state that a firm or a business unit engages in different levels of exploration and exploitation (Simsek, 2009). Scholars who adopt the realized perspective argue that firms can manage the tension created from the simultaneous engagement in exploration and exploitation by achieving balance or complementarity between these capabilities (Simsek, 2009). We focus on the realized perspective because it places more emphasis on how firms operationalize ambidexterity and obtain superior performance (e.g., NPP) by managing the levels of exploration and exploitation. The realized perspective addresses the challenge of effective resource allocation on exploration and exploitation within a firm better than structural and contextual perspectives. 
As shown in Appendix I, a review of the literature on the realized perspective of ambidexterity reveals that researchers have adopted $\mathrm{BD}$ and $\mathrm{CD}$ approaches to operationalize ambidexterity. The adoption of these approaches depends on the extent to which exploration and exploitation are treated as competing or orthogonal forces (Gupta et al., 2006; Simsek, 2009). In the next section, we explain the different nature and role of $\mathrm{BD}$ and $\mathrm{CD}$ in the context of product innovation. We develop a theoretical framework (Figure 1) to investigate distinct outcomes of BD and CD with respect to NPP. Building on the contingency perspective, we also examine the resource conditions that help maximize the effects of BD and CD on NPP.

\section{--- Figure 1 ---}

\section{Hypotheses}

Outcomes of balanced and combined dimensions of ambidexterity

Although pursuing both exploitative and exploratory product innovation is a critical prerequisite for successful new product development, exploitative and exploratory product innovation have different focuses and rely on processes that can be incompatible (Voss and Voss, 2013). Consequently, the simultaneous pursuit of these activities represents a paradox that may increase tension and result in negative outcomes (Gupta et al., 2006). This view is based on the argument that many firms due to resource boundaries cannot afford to engage in high levels of both exploitative and exploratory product innovation (Voss and Voss, 2013). Consequently, the trade-off between exploitative and exploratory product innovation is unavoidable to accommodate organizational limitations (Cao et al., 2009). An overemphasis on exploitative product innovation can create a narrow focus on refining and promoting the efficiency of existing processes, which may stifle the generation of new ideas to develop new 
products (see arguments on core-rigidity in He and Wong, 2004). An overemphasis on exploratory product innovation reflects an excessive focus on generating and experimenting new processes to develop novel and unique products, at the risk of failing to appropriate returns from costly experimentations (see discussions on failure-trap in Wei et al., 2014). Firms can avoid core-rigidity and failure-trap risks through managing the balance between the symmetric levels of these capabilities, which captures the notion of $\mathrm{BD}$ (He and Wong, 2004). Managing this balance reflects a manager's effort to avoid an excessive focus on either exploration or exploitation and ensure that appropriate effort is allocated to these activities. BD helps firms to balance their focus on exploring new product development, which assists in offering an innovative new product to customers and exploiting existing activities to ensure efficiency in new product development. Therefore,

H1a. BD has a positive effect on new product performance.

Many scholars view exploitative and exploratory product innovation as orthogonal, complementary forces. This view suggests that a firm can become ambidextrous by managing complementarity between the asymmetric levels of exploitative and exploratory product innovation, which captures the notion of CD (Cao et al., 2009). In particular, exploitative and exploratory product innovation do not compete for the same resources when they occur in different domains (Gupta et al., 2006). Consequently, the tension between exploitative and exploratory product innovation become negligible (Gupta et al., 2006). Further, many suggest that exploitative and exploratory product innovation are mutually enhancing, where engagement in greater levels of exploitation increases the capacity to engage in exploration and vice versa (Wei et al., 2014). Through repeated use of existing product innovation processes, firms have an advanced understanding of the functionality of existing activities and initiating various reconfigurations to develop novel product innovation activities (Gupta 
et al., 2006). Similarly, exploratory product innovation results in the creation of a larger pool of knowledge and activities, in which the exploitation of current activities can be applied in a greater scale (Cao et al., 2009). Because exploration of new product development activities and exploitation of existing activities across different domains complement each other, pursuing a high level of exploitative and exploratory product innovation in a complementary fashion maximizes the effect of both activities on NPP (Wei et al., 2014). Therefore, H1b. CD has a positive effect on new product performance.

\section{Moderating role of slack resources}

Resources are critical in emerging economy context, where firms need to overcome resource constraints and accelerating market dynamism. Firms under pressure from market dynamism in emerging economies need to develop new products and increase innovation speed to address market changes (Yuan and Chen, 2015). Resources are seen as intangible (e.g., knowledge) and tangible (e.g., physical) assets that enable firms to conceive and implement value-creating strategies (Barney, 1991). Prior studies have examined how high and low levels of available internal and external resources in combination with organizational capabilities result in superior performance (Danneels, 2008; Voss and Voss, 2013). Following this work, we contend that the benefits of BD and CD in achieving NPP are contingent on the levels of internal slack resources and the degree of social networking capability where external resources can be accessed for new product development.

We define slack resources as a pool of utilizable resources (e.g., financial and human) within a firm that are available to invest in developing new products (Chen et al., 2013; Troilo et al., 2014). The availability of slack resources enables firms to respond to environmental risks more effectively in a timely manner (Troilo et al., 2014). As discussed earlier, the potential benefit of $\mathrm{BD}$ is the mitigation of the risks (failure trap and core rigidity) 
of the failure to fully appropriate value from its innovation. Such risks can be mitigated when firms possess a high level of slack resources, because it provides a buffer to reduce potential risks that may have adverse effects on performance (Troilo et al, 2014). The performance of new product development with low levels of slack resources will be more affected as they might not possess sufficient resources to cushion such risks (Troilo et al., 2014). Consequently, achieving a high level of $\mathrm{BD}$ by symmetrically allocating resources to exploitative and exploratory product innovation is critical for firms with a low level of slack resources in order to avoid the potential risks of over-committing to one and neglecting another. Therefore,

H2a. Slack resources moderate the relationship between $B D$ and NPP, where the effect of BD on NPP is more beneficial when the level of slack resources is low than when it is high.

Prior literature suggested that the pursuit of a high level of both exploratory and exploitative product innovation is resource intensive (Sok and O'Cass, 2015) and will be taxing on available resources (Cao et al., 2009). Exploratory and exploitative product innovation reflect very different activities and may require different sets of supporting resources (Gupta et al., 2006). For example, to respond to competitive environments such as those in emerging economies, firms may need to set up and deploy different teams or units to perform different tasks - one may be responsible for discovering for new products/markets and another is responsible for maximizing returns from current products/markets (Sok and O'Cass, 2015). The team that is responsible for searching for new products and markets (exploratory team), instead of focusing on existing processes, emphasizes specifically on scanning of new knowledge and ideas that currently does not exist within the firm. The team that is responsible for appropriating returns from existing products and markets (exploitative 
team), on the other hand, emphasizes more specifically on mobilizing existing information and knowledge to enhance the efficiency of current processes (see comparable arguments in March, 1991).

Consequently, the successful pursuit $\mathrm{CD}$ is contingent on the availability of slack resources that can be allocated to support engagement in high levels of both exploitative and exploratory product innovation. A high level of slack resources provides firms the facilitating mechanism to pursue high levels of both exploitative and exploratory product innovation on NPP. In this sense, managers are less concerned about the competition between exploitative and exploratory product innovation and will be able to devote their attention to strategic opportunities and maximize the complementarity between these activities to address product and market opportunities. The performance of firms with a low level of slack resources will be affected if they pursue CD. Their efforts will be constrained when they do not have sufficient slack resources to support the effect of a high level of both exploitative and exploratory product innovation and thus NPP is diminished. Under this condition, exploitative and exploratory product innovation may be affected as significant slack resources are required to effectively pursue CD to enhance NPP. Therefore,

$H 2 b$. Slack resources moderate the relationship between $C D$ and NPP, where the effect of CD on NPP is more beneficial when the level of slack resources is high than when it is low.

\section{Moderating role of social networking capability}

Firms interact with their external environments (e.g., business partners, government agencies) and often depend on one another for complementary resources to successfully operate and fulfill their missions (Li et al., 2016). Consequently, the firm's ability to acquire external resources through managerial ties with business partners and political associations, especially 
in emerging economies, has received significant attention (Acquaah, 2007; Dong et al., 2013). Building on Sheng et al. (2011), we define social networking capability as a set of managerial connections with business partners and political officials who own complementary resources that can be beneficially directed toward a firm's new product development. Previous research suggests that accessing external resources are important for the successful new product development, particularly when it is costly or time consuming to be developed internally (Sheng et al., 2011). This is more so for firms in emerging markets, who are facing resources constraints and accelerating market dynamisms. These firms tend to leverage the existing institutional environment to their interest and foster their innovation efforts by developing social networks with external partners in order to reduce risks and uncertainties (Wu, 2011).

In the context of emerging economies, social networking capability is seen as the means to help firms to counter the lack of internal resources by providing the access to critical institutional support and resources (e.g., funds, tax subsidies) that are not available in the open market (Acquaah, 2007). Particularly, ties with other managers in a business network promote learning and resource transfer across firms within a business network, enabling them to access complementary external resources required to develop a new product. Studies from emerging economies in the Sub-Saharan, Middle-Eastern, and South Asian countries show ties with political officials also help firms to obtain scarce "insider" information and institutional support (e.g., funds, tax subsidies) (Acquaah, 2007; Dong et al., 2013). Many studies argue that while governments play an imperative role in the most of economies, this role even is more critical in many emerging economies where the government has a strong influence on the firms' access to specific external resources (Dong et al., 2013; Heirati and O'Cass, 2016). In this condition, ties with political officials may overcome the lack of established institutions by facilitating the firm's access to valuable 
resources and policy information that are necessary to develop a new product (Zhang and $\mathrm{Wu}, 2013)$. Therefore, a strong social networking capability has significant implications regarding the pursuit of ambidexterity.

As discussed earlier, firms that pursue BD are highly vulnerable to risks of tensions between exploratory and exploitative product innovation unless they possess appropriate buffering resources. We argue the failure to attain a high level of BD would not negatively influence NPP if they possess a high level of social networking capability. Firms can acquire additional resources needed for new product development from external sources such as government agencies and business partners (Wu, 2011; Heirati and O'Cass, 2016) to alleviate any potential risks when and/or if they emerge. On the contrary, when the level of social networking capability is low, balancing exploitative and exploratory product innovation is critical for firms to manage symmetric resource allocation and avoid either the failure-trap or core-rigidity risks. Therefore,

H3a. Social networking capability moderates the relationship between BD and NPP, where the effect of BD on NPP is more beneficial when the level of social networking capability is low than when it is high.

As discussed earlier, the effective pursuit of $\mathrm{CD}$ requires substantial resources to support pursuing high levels of both exploitative and exploratory product innovation. Firms with a low level of social networking capability may face difficulties in possessing necessary resources to effectively engage in high levels of both exploitative and exploratory product innovation. We argue that firms with a high level of social networking capability are able to access external resources that are not available internally through their networks, enabling them to overcome resource constraints (Acquaah, 2007; Dong et al., 2013). Consequently, success at pursuing $\mathrm{CD}$ is contingent on the level of social networking capability to access 
external resources. In this sense, managers are less concerned about the competition between exploitative and exploratory product innovation and will be able to devote their attention to maximizing the complementarity between these activities to develop a new product. Thus, possessing external resources embedded in business and political social network provides firms the facilitating mechanism to maximize the effect of CD on NPP. Therefore, H3b. Social networking capability moderates the relationship between CD and NPP, where the effect of CD on NPP is more beneficial when the level of social networking capability is high than when it is low.

\section{Method}

We employed a questionnaire to collect the data from a sample of high technology firms in Iran, a "Next Eleven" emerging economy. The sample consists of high-technology firms from a wide range of industries, including automotive, telecommunication equipment, electronics, industrial machinery, and chemical. Undertaking both exploitative and exploratory product innovation is important for high technology firms because they need to respond to rapid market changes, disruptive technologies, and intensive competition (Lin et al., 2017). With growing numbers of new products originating from emerging economies and increasing numbers of research and development centers being developed in emerging economies by multinational firms (Subramaniam et al., 2015), it is critical to understand how ambidexterity helps firms operating in emerging economies to successfully develop new products. Iran as a member of the "Next Eleven" has the potential of becoming one of the world's largest economies (Wilson and Stupnytska, 2007). Iran's Industrial Production growth averaged 6.9\% from 1975 until 2010, reaching 10.1\% in 2010, higher than all BRICS (Brazil, Russia, India, China, and South Africa) countries. 
We collected data from large (over 200 employees) firms for two reasons. First, firm size as indicated by the number of employees does not account for whether a firm has a larger or smaller market size and corresponding financial assets (Katila and Shane, 2005). Second, large firms also have distinct and various management levels (e.g., operational and corporate levels) with different levels of responsibilities within the firms and therefore, one might have a better understanding on a particular activity than another. For instance, the mid-level manager (e.g., R\&D manager) would have a better understanding of innovation activities of a particular project compared to the senior manager (e.g., CEO), thus a R\&D manager is the best representation to address questions related to innovation. Similarly, senior manager would have a better understanding of the amount of resources firms possess and the level of networks with various stakeholders which are often forged at the corporate level. Therefore, senior manager is the best representation to address questions related to resources and networking. This gives us an opportunity to employ a multiple informant design to capture data related to the corporate-level and operational-level variables. Consequently, two separate surveys were developed. In Survey A, the senior manager (CEO) was asked to address questions at corporate level related to slack resources, social networking capability, and control variables. In Survey B, the mid-level manager (product or R\&D manager) was asked to address questions at operational level related to exploitative and exploratory product innovation and NPP. Data from two hierarchical levels (management levels) offers superior quality data and helps overcome the common bias issue of the single informant samples (see Sok and O’Cass, 2015).

We randomly selected 800 large firms from a business directory and checked whether the selected firms had marketed at least one new product during the previous year. We only focused on new products launched within the previous year, because it is advocated that high technology firms frequently introduce new products and replace previous product lines with 
new lines (e.g., electronic devices) due to short product lifecycles and pace of market changes (Yuan and Chen, 2015). We also prescreened the level of the identified new product's newness. Following Tsai et al. (2008), we asked respondents to score the identified new product on a three-point scale: this new product (1) is the incrementally improved version of an existing product; (2) is new to the firm, but it is not new to the market; and (3) is new to both the firm and the market. We did not invite firms who scored 1 to ensure that the new products had a relative level of newness to the firm and the market.

We invited 538 firms that met the selection criteria to participate in the study. We selected a new product randomly for firms that launched many new products during the previous year, and we provided an instruction requesting respondents to answer questions focusing on the selected new product. In the information sheet, we also explained that this questionnaire focuses the organizational processes undertaken for the development of the selected new product. We collected 200 survey packages (400 respondents: two questionnaires per firm) for a participation rate of $19.5 \%$. We asked respondents to indicate their knowledgeability regarding issues asked in the questionnaire using a seven-point scale. We eliminated respondents that scored below four. The final sample decreased to 156 firms. The mean scores of the informants' knowledgeability was over 5 out of 7 .

The average firm age was 28 years and firm size was 690 employees. $72.7 \%$ of studied firms launched 1 to 5 new products and 28.3\% launched over 5 new products during the previous year. Therefore, the studied firms had a significant investment in new product development over the previous year. Non-response bias was not evident, as the difference between the size and age of the participating and non-participating firms was not significant at $\mathrm{p}>0.05$.

\section{Measures}


Following Homburg et al. (2011), we generated and modified measures for all constructs from the existing literature to ensure that all measures suited the context of the study. We sent the modified items to researchers in the area of innovation management and marketing who judged the precision and representativeness of items for each construct. The judges were asked to evaluate each item as "not representative", "somewhat representative", or "very representative" with respect to the constructs' definition. Then, we interviewed with six managers to ensure understandability and robustness of items. On the basis of the input received, we eliminated some items and modified some into the final questionnaires. Finally, we pre-tested the questionnaire using 20 managers to assess the validity of the measures.

We measured exploratory product innovation using four items drawn from Danneels (2008) and Peng et al. (2008). We measured exploitative product innovation using four items drawn from Peng et al. (2008) and He and Wong (2004). We measured NPP using four items drawn from Tsai et al. (2008). Slack resources were measured using four items from Danneels (2008). Social networking capability was measured as the second-order construct comprising the levels of business and political ties. Four items were adopted Atuahene-Gima and Murray (2007) to measure business ties and three items were adopted from Heirati and O'Cass (2016) to measure political ties. We measured all items on a seven-point Likert-type scale of " $1=$ not at all" to " 7 = very much so" (Appendix II outlines all measures).

Ambidexterity. Following the approach suggested by Lubatkin et al. (2006), and Cao et al. (2009), we operationalized BD and CD through a three-step procedure. First, we ran an unconstrained regression equation in which exploitative and exploratory product innovation were two separate independent variables and NPP was the dependent variable. Second, we ran a constrained regression equation in which exploitative and exploratory product innovation were merged into a single index by calculating the absolute difference between exploratory and exploitative product innovation (see also Fernhaber and Patel, 2012). Third, 
we ran a constrained regression equation in which exploitative and exploratory product innovation were merged into a single index by multiplying them. The constrained regression equations in step two and three represent $\mathrm{BD}$ and $\mathrm{CD}$, respectively. In this sense, the stronger effect of BD on NPP reflects the imbalance between exploitative and exploratory product innovation, while the stronger effect of $\mathrm{CD}$ on NPP reflects the higher level of the combination between exploitative and exploratory product innovation. To facilitate the interpretation of outcomes of BD, we reversed the magnitude of BD by multiplying it by "-1" (Cao et al., 2009). Thus, the stronger effect of reversed BD on NPP reflects the higher level of balance between exploitative and exploratory product innovation.

Control Variables. We considered market uncertainty, technology uncertainty, firm age, and firm size as control variables. We focused on these variables as past research shows their potential to influence the outcomes of exploratory and exploitative activities (Voss and Voss, 2013). Market and technology uncertainty were measured using three items each from De Luca and Atuahene-Gima (2007). We measured firm age using the number of years since a firm was founded and firm size using the number of employees.

\section{Analysis and Results}

We examined the reliability and validity of multi-item measures using the confirmatory factor analysis (CFA). The fit indices are as follows: $\chi^{2} / \mathrm{df}=1.30, \mathrm{p}<0.01 ; \mathrm{CFI}=0.96$; TLI $=0.95$; RMSEA $=0.04$, indicating a reasonably good fit. All indicators had satisfactory loadings ( $>$ $0.50)$ and critical ratios $(>1.96)$. As indicated in Table 1, all constructs had satisfactory average variance extracted $(\mathrm{AVE}>0.50)$ and composite reliability $(\mathrm{CR}>0.70)$, indicating that the acceptable convergent validity. The square root of the AVEs were greater than all individual correlations in Table 2, indicating satisfactory discriminant validity. Multicollinearity was not a concern as the maximum VIF was 2.32 . We also examined for the 
threat of common method variance (CMV) using the CFA approach. We also tested a single factor model by linking all items of the dependent and independent factors to a single factor. This model did not fit the data well $\left(\chi^{2} / \mathrm{df}=3.98, \mathrm{GFI}=0.63, \mathrm{TLI}=0.53, \mathrm{CFI}=0.47\right.$, RMSEA=0.14). These results suggest no significant threat of CMV.

\section{--- Table 1 ---}

\section{Hypotheses Results}

We employed hierarchical regression analysis (SPSS Statistics 23) to examine hypotheses through a four-step procedure recommended by He and Wong (2004) and Wei et al. (2014). In Step 1 we examined the effect of control variables (Model 1 in Table 2). In Step 2, we examined the effect of the main variables and control variables through a base model with respect to NPP (Model 2). We used exploitative and exploratory product innovation as the independent variables in the base model. In Step 3, BD and CD were added to the base model (Models 3 and 4). In Step 4, the interaction effects between BD, CD, slack resources, and social networking capability were included in Models 5 to 7 . To evaluate whether the interaction effect significantly improves the explanatory power of the model, we calculated the increases in $\mathrm{R}^{2}\left(\Delta \mathrm{R}^{2}\right)$ between Models 1 to 7 . The results indicate that $\Delta \mathrm{R}^{2}$ attributable to the interaction effects is statistically different from zero, indicating a significant moderation effect.

Model 1 indicates none of the control variables significantly influenced NPP. As shown in Table 2, both $\mathrm{BD}(\beta=0.45, \mathrm{p}<0.01)$ and $\mathrm{CD}(\beta=0.20, \mathrm{p}<0.05)$ positively influenced NPP supporting H1a and H1b. Regarding $\mathrm{H} 2 \mathrm{a}$, the results indicate that slack resources did not significantly moderate the relationships between BD and NPP $(\beta=-0.02$, ns), rejecting H2a. However, slack resources positively moderated the effect of CD on NPP $(\beta=0.21$, $\mathrm{p}<0.05$ ), supporting $\mathrm{H} 2 \mathrm{~b}$. We performed single slope analysis to illustrate the moderation 
effect of slack resources. Figure 2 shows the relationship between CD and NPP is stronger the level of slack resources is high ( $1 \mathrm{SD}$ above mean: $\beta=4.05, \mathrm{p}<0.05)$ than when the level of slack resources is low ( $1 \mathrm{SD}$ below mean: $\beta=3.31, \mathrm{~ns})$.

Finally, the results support $\mathrm{H} 3 \mathrm{a}$ and $\mathrm{H} 3 \mathrm{~b}$ by showing that social networking capability negatively moderated the relationships between BD and NPP $(\beta=-0.17, p<0.05)$ and positively moderated the relationships between $\mathrm{CD}$ and NPP $(\beta=0.17, \mathrm{p}<0.05)$. Figure 2 indicates the effect of BD on NPP is weaker when the level of social networking capability is high (1 SD above mean: $\beta=2.70, \mathrm{~ns}$ ) compared to when the level social networking capability was low (1 SD below mean: $\beta=3.10, p<0.05$ ). Further, Figure 2 shows the effect of $\mathrm{CD}$ on NPP is greater when the level of social networking capability is high (1 SD above mean: $\beta=2.93, p<0.05$ ) compared to when the level social networking capability was low (1 SD below mean: $\beta=2.43$, ns).

\section{--- Table 2 ---}

--- Figure 2 ---

\section{Discussion and Conclusions}

This study contributes to the literature in several ways. First, we extend the literature by providing a contingency perspective on the balanced and combined dimensions of ambidexterity; arguably two of the most employed approaches to operationalize ambidexterity (Cao et al., 2009; Wei et al., 2014). We advance the literature by investigating the contingent effect of slack resources and social networking capability in facilitating the firm's ability to maximize the outcomes of the balanced dimension versus combined dimension of ambidexterity with respect to NPP in the context of high technology firms operating in an emerging economy. We extend prior research that show organizational characteristics influence the outcomes of ambidexterity, and sheds light on the specific 
resource conditions under which high technology firms operating in an emerging economy should pursue BD or CD to drive NPP.

We show slack resources and social networking capability have positive moderating effects on the relationship between CD and NPP but not between BD and NPP. These findings imply that when the level of slack resources increases, the relationship between CD and NPP is enhanced, while the relationship between BD and NPP is weakened. These findings highlight that the pursuit of CD and maximizing its effect on NPP is justifiable, when firms possess greater levels of slack resources. Departing from existing studies that view firm size as the key determinant of a firm's available resources (Cao et al., 2009), we argue that firm size does not necessarily account for whether firms invest all or a sufficient amount of resources in new product development projects and view slack resources as the effective determinant of the level of internal resources available for new product development activities. Further, departing from existing studies that view slack resources as prerequisites for radical innovation (e.g., Troilo et al., 2014), we also advance the literature by showing that slack resources allow firms to more flexibly allocate available resources to exploitative and exploratory product innovation to develop new products in emerging economies.

The findings further show when the level of social networking capability increases, the relationship between CD and NPP is enhanced, yet the relationship between BD and NPP is weakened. Departing from existing studies that view environmental munificence as the key determinant of available external resources (e.g., Cao et al., 2009), we contend that environmental munificence does not truly represent the firm's ability to access external resources. A high average sales growth of firms in the industry does not necessarily result in the firm's ability to access external resources that belong to other firms. In focusing on the role of social networking capability in the emerging economies context, we adopt the position that social networking capability acts as a mechanism that helps firms to access resources not 
available to all actors in a market and to cope with resource constraints that exist in emerging economies. Our findings also extend Atuahene-Gima and Murray (2007) who show that ties with other firms drive the levels of Top Management Team exploitative and exploratory learning independently. Particularly, while Atuahene-Gima and Murray (2007) focus on the role of business ties and learning, we investigate the extent that social networking capability, as the combination of political and business ties, affects a firm's approach to managing ambidexterity. Our results highlight that promoting social networking capability is necessary to maximize the benefits of $\mathrm{CD}$ in the context of emerging economies.

Our results help shed light on the debate in the ambidexterity literature regarding the firm's ability to simultaneously pursue exploitation and exploration. While some researchers see pursuing exploration and exploitation simultaneously as a zero-sum (or trade-off) game (e.g., March, 1991), recent studies suggest that exploration and exploitation are mutually enhancing rather than in fundamental opposition (e.g., Cao et al., 2009; O'Cass et al., 2015). The results suggest that exploration and exploitation can be interpreted as mutually enhancing or in fundamental opposition depending on the level of resource availability. The results indicate that firms benefit the most from achieving a balance of exploitation and exploration when the level of slack resources or social networking capability is low than when it is high. However, firms benefit most from engaging in high levels of both exploitation and exploration in a complementary fashion when the level of slack resources or social networking capability are high rather than when they are low. These results suggest that exploration and exploitation are better viewed as in fundamental opposition for resourceconstrained firms while exploration and exploitation are better viewed as mutually enhancing for resource abundant firms. In this sense, the trade-offs between exploration and exploitation can be alleviated if firms possess sufficient slack resources or have the abilities to access external resources. 


\section{Managerial Implications}

This study offers two managerial implications. We advise managers to avoid investing all available resources (e.g., hiring new employees, developing teams) to pursue high levels of exploration and exploitation when they do not have sufficient slack resources. Firms need to maintain a high level of discretionary resources to buffer tensions between exploratory versus exploitative activities. We advise managers not to distribute all dividends (profits) to shareholders; yet retain sufficient resources for future projects, which are necessary for firms operating in emerging economies where firms need to respond quickly to market changes induced by intense competition. We recommend managers to develop a long-term or a backup financial plan by making a separated discretionary account to save a portion of the current surplus profit. This discretionary account helps to support new product development activities particularly during hard times (e.g., recession).

On this resource point, we advise managers to build personal connections with business partners and government officials to access external resource and support product development activities, particularly in emerging economies. Although this implication might be less critical to established firms with strong business and political network in emerging economies, it is profound for potential new entrants, particularly foreign firms. When legal enforcement is inefficient, the use of political and business ties helps foreign firms to lessen unlawful behaviors and unfair competition by existing rivals in the market. Emerging economies have seen an influx of foreign investment and develop research and development centers through acquisition or joint venture partners. Given the critical role of social networking to possess external resources and institutional supports, foreign investors should look for partnership with local firms and managers that facilitate the development of sound 
business and political ties. Even when teaming up with local firms, foreign investors should invest a portion of their profit in strengthening their business and political social networks.

\section{Limitations and Future Research Recommendations}

This study has several limitations. First, we employed the cross-sectional data with potential risk of causal inference. Future research can investigate the relationships between ambidexterity and NPP through a longitudinal research. Second, our sample is based on the manufacturing firms, therefore our findings might vary for other industries (e.g., service firms). Besides these limitations, there are several promising avenues for future research. First, we conceptualized ambidexterity as the simultaneous pursuit of exploratory and exploitative product innovation. Future research could extend our work by conceptualizing ambidexterity within other functional areas such as manufacturing and marketing. Further, we show the value of $\mathrm{BD}$ and $\mathrm{CD}$ is contingent on the available internal and external resources. Future, our sample is based on new products that are new to the firm and/or to the market. Thus, we did not focus on new products that are incrementally improved version of an existing product. In this sense, exploitative product innovation had relatively weaker effect on NPP compared to exploratory product innovation. Future studies can examine the contingent outcomes of $\mathrm{BD}$ and $\mathrm{CD}$ through separated samples of new products and incrementally improved existing products. 


1
2
3
4
5
6
7
8
9
10
11
12
13
14
15
16
17
18
19
20
21
22
23
24
25
26
27
28
29
30
31
32
33
34
35
36
37
38
39
40
41
42
43
44
59
50
50
56
50
48
49
50
51
52
50

10

11

12

13

14

15

16

18

19

20

21

22

23

24

27

28

29

30

33

34

35

36

37

38

39

40

42

43

44

45

46

48

49

50

51

52

53

54

56

57

58

60 


\section{Appendix I: Literature on the operationalization of ambidexterity}

\begin{tabular}{|c|c|c|c|c|}
\hline Research & Context & $\begin{array}{c}\text { Operationalization } \\
\text { Approach }\end{array}$ & Level of analysis & Performance outcomes \\
\hline He and Wong (2004) & $\begin{array}{l}\text { Technological } \\
\text { innovation }\end{array}$ & $\mathrm{BD} \& \mathrm{CD}$ & Firm & Firm performance \\
\hline Lavie and Rosenkopf (2006) & Alliance formation & $\mathrm{BD}$ & Firm & Firm performance \\
\hline $\begin{array}{l}\text { Atuahene-Gima and Murray } \\
(2007)\end{array}$ & $\begin{array}{l}\text { Organizational } \\
\text { learning }\end{array}$ & $\mathrm{CD}$ & Firm & New product performance \\
\hline Jansen et al. (2008) & $\begin{array}{l}\text { Technological } \\
\text { innovation }\end{array}$ & $\mathrm{CD}$ & Firm & Firm performance \\
\hline Morgan and Berthon (2008) & $\begin{array}{l}\text { Technological } \\
\text { innovation }\end{array}$ & $\mathrm{BD}$ & Firm & Firm performance \\
\hline Menguc and Auh (2008) & $\begin{array}{l}\text { Organizational } \\
\text { learning }\end{array}$ & $\mathrm{CD}$ & Firm & Firm performance \\
\hline Cao et al. (2009) & $\begin{array}{l}\text { Technological } \\
\text { innovation }\end{array}$ & $\mathrm{BD} \& \mathrm{CD}$ & Firm & Firm performance \\
\hline Vorhies et al. (2011) & Marketing capability & $\mathrm{BD}$ & Firm & Firm performance \\
\hline Lee and Huang (2012) & $\begin{array}{l}\text { Organizational } \\
\text { learning }\end{array}$ & $\mathrm{CD}$ & Firm & Firm performance \\
\hline Jansen et al. (2012) & $\begin{array}{l}\text { Technological } \\
\text { innovation }\end{array}$ & $\mathrm{CD}$ & Business unit & Business unit performance \\
\hline Siren et al. (2012) & $\begin{array}{l}\text { Entrepreneurship } \\
\text { strategy }\end{array}$ & $\mathrm{BD}$ & Firm & Firm performance \\
\hline Fernhaber and Patel (2012) & $\begin{array}{l}\text { Technological } \\
\text { innovation }\end{array}$ & $\mathrm{BD}$ & Firm & Firm performance \\
\hline Li and Huang (2012) & $\begin{array}{l}\text { Technological } \\
\text { innovation }\end{array}$ & $\mathrm{CD}$ & Business unit & New product performance \\
\hline Chang and Hughes (2012) & $\begin{array}{l}\text { Technological } \\
\text { innovation }\end{array}$ & $\mathrm{BD}$ & Firm & Firm performance \\
\hline $\begin{array}{l}\text { Blindenbach Driessen and } \\
\text { Ende (2014) }\end{array}$ & Strategic Orientation & $\mathrm{CD}$ & Firm & * \\
\hline Hill and Birkinshaw (2014) & $\begin{array}{l}\text { Technological } \\
\text { innovation }\end{array}$ & $\mathrm{BD} \& \mathrm{CD}$ & Business unit & Business unit performance \\
\hline Wei et al. (2014) & $\begin{array}{l}\text { Technological } \\
\text { innovation }\end{array}$ & $\mathrm{BD} \& \mathrm{CD}$ & Firm & New product development \\
\hline Dai et al. (2017) & $\begin{array}{l}\text { Technological } \\
\text { innovation }\end{array}$ & $\mathrm{BD}$ & Firm & * \\
\hline Lin et al. (2017) & $\begin{array}{l}\text { Technological } \\
\text { innovation }\end{array}$ & $\mathrm{CD}$ & Firm & $*$ \\
\hline
\end{tabular}

* This study operationalizes ambidexterity as the dependent (outcome) variable. 


\section{Appendix II: Measures}

Exploratory product innovation - To develop this new product, our firm:

Loading

... acquired entirely new product development processes that had not been used before by the firm. 0.86

$\begin{array}{lr}\text {....acquired completely new technologies and processes that had not been used before by the firm. } & 0.88\end{array}$

....acquired entirely new technology and R\&D training skills for personnel development. 0.86

...set up completely new types of product development facilities and operations. $\quad 0.82$

Exploitative product innovation - To develop this new product, our firm:

...improved its existing product development processes aimed at quality improvement. 0.74

$\begin{array}{lr}\text {...exploited mature, existing technologies to enhance the efficiency of product development. } & 0.88\end{array}$

$\begin{array}{lr}\text {...improved existing processes to reduce the cost of product development. } & 0.72\end{array}$

$\begin{array}{ll}\text {....refined existing processes to reduce production time. } & 0.77\end{array}$

Slack resources - To develop this new product, we had access to:

$\begin{array}{lr}\text {....available resources for new (e.g., future) projects. } & 0.85\end{array}$

$\begin{array}{lr}\text {...discretionary financial resources. } & 0.90\end{array}$

$\begin{array}{lr}\text {...manpower to work on special projects. } & 0.81\end{array}$

....an amount of resources in reserve.*

Social Networking Capability - In the development of this product our firm has:

Business Ties

$\begin{array}{lr}\text {...extensively utilized relationships with managers of firms outside our industry. } & 0.82\end{array}$

$\begin{array}{lr}\text {...extensively utilized relationships with managers of firms in our industry. } & 0.82\end{array}$

$\begin{array}{ll}\text {....acquired information related to our product-market strategies from interactions with other firms. } & 0.73\end{array}$

Political Ties

...extensively utilized relationships with government officials in various levels of government. 0.91

...extensively utilized relationships with officials in regulatory organizations such as tax bureaus and state banks. 0.91

...acquired information related to our product-market strategies (e.g., government regulations, tariffs, taxation) $\quad 0.83$

from our interactions with government officials.

New Product Performance - This new product achieved the following goals set by our firm:

...met revenue goals.

0.89

...met sales growth goals.

0.79

...met market share goals.

0.77

...met profitability goals.

0.77

*: This item is deleted during the scale purification and CFA process. 


\section{References}

Acquaah, M. (2007), "Managerial Social Capital, Strategic Orientation, and Organizational Performance in an Emerging Economy", Strategic Management Journal, Vol. 28 No. 12, pp. 1235-1255.

Atuahene-Gima, K. (2005), "Resolving the Capability-Rigidity Paradox in New Product Innovation", Journal of Marketing, Vol. 69 No. 4, pp. 61-83.

Atuahene-Gima, K. and Murray, J.Y. (2007), "Exploratory and Exploitative Learning in New Product Development: A Social Capital Perspective on New Technology Ventures in China", Journal of International Marketing, Vol. 15 No. 2, pp. 1- 29.

Barney, J.B. (1991), "Firms Resources and Sustained Competitive Advantage", Journal of Management, Vol. 17 No. 1, pp. 99-120.

Blindenbach $\square$ Driessen, F., and Ende, J. (2014), "The locus of innovation: The effect of a separate innovation unit on exploration, exploitation, and ambidexterity in manufacturing and service firms", Journal of Product Innovation Management, Vol. 31 No. 5, pp. 1089-1105.

Cao, Q., Gedajlovic, E. and Zhang, H. (2009), "Unpacking Organizational Ambidexterity: Dimensions, Contingencies, and Synergistic Effects", Organization Science, Vol. 20 No. 4, pp. 781-796.

Chang, Y.-Y., and M. Hughes (2012), "Drivers of innovation ambidexterity in small-to medium-sized firms", European Management Journal, Vol. 30 No. 1, pp. 1-17.

Chen, Y.C., Li, P.C., and Lin, Y.H. (2013), "How Inter-and Intra-Organizational Coordination Affect Product Development Performance: The Role of Slack Resources”, Journal of Business \& Industrial Marketing, Vol. 28 No. 2, pp. 125-136.

Daia, Y., K. Dub, G. Byuna, and X. Zhuc (2017), “Ambidextrous in new ventures: The impact of new product development alliances and transactive memory systems", Journal of Business Research, Vol. 75, pp. 77-85.

Danneels, E. (2008), “Organizational Antecedents of Second-Order Competences”, Strategic Management Journal, Vol. 29 No. 5, pp. 519-543.

De Luca, L.M. and Atuahene-Gima, K. (2007), "Market Knowledge Dimensions and CrossFunctional Collaboration: Examining the Different Routes to Product Innovation Performance", Journal of Marketing, Vol. 71 No. 1, pp. 95-112. 
Dong, M.C., Li, C.B. and Tse, D.K. (2013), "Do Business and Political Ties Differ in Cultivating Marketing Channels for Foreign and Local Firms in China?", Journal of International Marketing, Vol. 21 No. 1, pp. 39-56.

Eltantawy, R.A. (2016), "The Role of Supply Management Resilience in Attaining Ambidexterity: A Dynamic Capabilities Approach", Journal of Business \& Industrial Marketing, Vol. 31 No. 1, pp. 123-134.

Fernhaber, S.A. and Patel, P.C. (2012), "How Do Young Firms Manage Product Portfolio Complexity? The Role of Absorptive Capacity and Ambidexterity", Strategic Management Journal, Vol. 33 No. 13, pp. 1516-1539.

Gupta, A.K., Smith, K.G., and Shalley, C.E. (2006), “The Interplay between Exploration and Exploitation", Academy of Management Journal, Vol. 49 No. 4, pp. 693-706.

He, Z.L. and Wong, P.K. (2004), "Exploration vs. Exploitation: An Empirical Test of the Ambidexterity Hypothesis”, Organization Science, Vol. 15 No. 4, pp. 481-494.

Heirati, N. and O'Cass, A. (2016), "Supporting New Product Commercialization through Managerial Social Ties and Market Knowledge Development in an Emerging Economy”, Asia Pacific Journal of Management, Vol. 33 No. 2, pp. 411-433.

Hill, S. A., and J. Birkinshaw (2014), "Ambidexterity and survival in corporate venture units", Journal of Management, Vol. 40 No. 7, pp. 1899-931.

Homburg, C., Müller, M. and Klarmann, M. (2011), "When Should the Customer Really Be King? On the Optimum Level of Salesperson Customer Orientation in Sales Encounters", Journal of Marketing, Vol. 75 No. 2, pp. 55-74.

Jansen, J. J. P., G. George, F. A. van den Bosch, and H. W. Volberda (2008), "Senior team attributes and organizational ambidexterity: The moderating role of transformational leadership”, Journal of Management Studies, Vol. 45 No. 5, pp. 982-1007.

Jansen, J. J. P., Z. Simsek, and Q. Cao (2012), “Ambidexterity and performance in multiunit contexts: Cross-level moderating effects of structural and resource attributes", Strategic Management Journal, Vol. 33 No. 11, pp. 1286-303.

Katila, R. and Shane, S. (2005), "When Does Lack of Resources Make New Firms Innovative?”, Academy of Management Journal, Vol. 48 No. 5, pp. 814-829.

Lavie, D., U. Stettner, and M. L. Tushman (2010), "Exploration and exploitation within and across organizations," The Academy of Management Annals, Vol. 4 No. 1, pp. 109-55.

Lee, C.Y., and Y.C. Huang (2012), "Knowledge stock, ambidextrous learning, and firm performance: Evidence from technologically intensive industries", Management Decision, Vol. 50 no. 6, pp. 1096-116. 
Li, Y.H., and Huang, J.W. (2012), “Ambidexterity's mediating impact on product development proficiency and new product performance", Industrial Marketing Management, Vol. 41 No. 7, pp. 1125-32.

Li, Y., Zhang, Y., and Zheng, S. (2016), "Social Capital, Portfolio Management Capability and Exploratory Innovation: Evidence from China", Journal of Business \& Industrial Marketing, Vol. 31 No. 6, pp. 794-807.

Lin, H. E., McDonough, E. F., Yang, J., and Wang, C. (2017), “Aligning Knowledge Assets for Exploitation, Exploration, and Ambidexterity: A Study of Companies in High $\square$ Tech Parks in China”, Journal of Product Innovation Management, Vol. 34 No. 2, pp. 122-140.

Lubatkin, M.H., Simsek, Z., Ling, Y. and Veiga, J.F. (2006), "Ambidexterity and Performance in Small-to Medium-Sized Firms: The Pivotal Role of Top Management Team Behavioral Integration", Journal of Management, Vol. 32 No. 5, pp. 646-672.

March, J. G. (1991), "Exploration and exploitation in organizational learning”, Organization Science, Vol. 2 No. 1, pp. 71-87.

Mellahi, K., Demirbag, M. and Riddle, L. (2011), "Multinationals in the Middle East: Challenges and Opportunities”, Journal of World Business, Vol. 46 No. 4, pp. 406-410.

Menguc, B., and S. Auh (2008), "The asymmetric moderating role of market orientation on the ambidexterity-firm performance relationship for prospectors and defenders," Industrial Marketing Management, Vol. 37 No. 4, pp. 455-70.

Morgan, R. E., and P. Berthon (2008), "Market orientation, generative learning, innovation strategy and business performance inter-relationships in bioschience firms", Journal of Management Studies, Vol. 45 No. 8, pp. 1329-1353.

O'Cass, A., Heirati, N. and Ngo, L.V. (2014), “Achieving new product success via the synchronization of exploration and exploitation across multiple levels and functional areas", Industrial Marketing Management, Vol. 43 No. 5, pp. 862-872.

Peng, D.X., Schroeder, R.G. and Shah, R. (2008), "Linking Routines to Operations Capabilities: A New Perspective", Journal of Operations Management, Vol. 26 No. 6, pp. 730-748.

Sheng, S., Zhou, N. and Li, J.J. (2011), "The Effects of Business and Political Ties on Firm Performance: Evidence from China", Journal of Marketing, Vol. 75 No. 1, pp. 1-15.

Siren, C. A., M. Kohtamäki, and A. Kuckertz (2012), "Exploration and exploitation strategies, profit performance, and the mediating role of strategic learning: Escaping the exploitation trap", Strategic Entrepreneurship Journal, Vol. 6 No. 1, pp. 18-41. 
Sok, P. and O'Cass, A. (2015), "Examining the New Product Innovation-Performance Relationship: Optimizing the Role of Individual-level Creativity and Attention-toDetail”, Industrial Marketing Management, Vol. 47 No. May, pp. 156-165.

Subramaniam, M., Ernst, H. and Dubiel, A. (2015), "From the Special Issue Editors: Innovations for and from Emerging Markets", Journal of Product Innovation Management, Vol. 32 No. 1, pp. 5-11.

Troilo, G., De Luca, L.M. and Atuahene-Gima, K. (2014), "More Innovation with Less? A Strategic Contingency View of Slack Resources, Information Search, and Radical Innovation", Journal of Product Innovation Management, Vol. 31 No. 2, pp. 259-277.

Tsai, K.H., Chou, C. and Kuo, J. H. (2008), “The Curvilinear Relationships between Responsive and Proactive Market Orientations and New Product Performance: A Contingent Link", Industrial Marketing Management, Vol. 37 No. 8, pp. 884-894.

Vorhies, D. W., L. M. Orr, and V. D. Bush (2011), "Improving customer-focused marketing capabilities and firm financial performance via marketing exploration and exploitation”, Journal of the Academy of Marketing Science, Vol. 39 No. 5, pp. 736-56.

Voss, G.B. and Voss, Z.G. (2013), "Strategic Ambidexterity in Small and Medium-Sized Enterprises: Implementing Exploration and Exploitation in Product and Market Domains”, Organization Science, Vol. 24 No. 5, pp. 1459 - 1477.

Wei, Z., Yi, Y. and Guo, H. (2014), “Organizational Learning Ambidexterity, Strategic Flexibility, and New Product Development", Journal of Product Innovation Management, Vol. 31 No. 4, pp. 832-847.

Wilson, D. and Stupnytska, A. (2007). The N-11: More than an acronym (Vol. Paper No. 153): Goldman Sachs Global Economics.

Wu, J. (2011), "Asymmetric Roles of Business Ties and Political Ties in Product Innovation", Journal of Business Research, Vol. 64 No. 11, pp. 1151-1156.

Yuan, L. and Chen, X. (2015), "Managerial Learning and New Product Innovativeness in High-Tech Industries: Curvilinear Effect and the Role of Multilevel Institutional Support”, Industrial Marketing Management, Vol. 50 No. October, pp. 51-59.

Zhang, J. and Wu, W.P. (2013), "Social Capital and New Product Development Outcomes: The Mediating Role of Sensing Capability in Chinese High-Tech Firms", Journal of World Business, Vol. 48 No. 4, pp. 539-548. 
Table 1: Correlation Matrix

\begin{tabular}{|c|c|c|c|c|c|c|c|c|c|}
\hline & 1 & 2 & 3 & 4 & 5 & 6 & 7 & 8 & 9 \\
\hline 1 Exploratory product innovation & 0.85 & & & & & & & & \\
\hline 2 Exploitative product innovation & $0.41^{* *}$ & 0.78 & & & & & & & \\
\hline 3 Slack resources & $0.35^{* *}$ & $0.26^{*}$ & 0.85 & & & & & & \\
\hline 4 Social networking capability & $0.28^{* *}$ & 0.13 & 0.09 & 0.87 & & & & & \\
\hline 5 New product performance & $0.44^{* *}$ & $0.22^{* *}$ & $0.32^{* *}$ & $0.18^{*}$ & 0.81 & & & & \\
\hline 6 Technological uncertainty & $0.19^{*}$ & 0.13 & 0.07 & -0.09 & -0.09 & 0.92 & & & \\
\hline 7 Market uncertainty & 0.12 & $0.18^{*}$ & 0.16 & 0.06 & -0.01 & $0.34^{* *}$ & 0.94 & & \\
\hline 8 Firm Age & $0.25^{* *}$ & 0.11 & 0.12 & 0.10 & -0.01 & -0.01 & 0.15 & 1.00 & \\
\hline 9 Firm size & 0.16 & $0.20^{*}$ & 0.03 & 0.08 & -0.08 & 0.16 & $0.20^{*}$ & $0.41^{* *}$ & 1.00 \\
\hline AVE & 0.73 & 0.61 & 0.72 & 0.76 & 0.65 & 0.85 & 0.88 & - & - \\
\hline CR & 0.91 & 0.86 & 0.89 & 0.86 & 0.88 & 0.92 & 0.93 & - & - \\
\hline
\end{tabular}

Notes: Diagonal entries show the square roots of average variance extracted. Others represent correlation coefficients. * and ** indicate the significance level at 0.05 and 0.01 (two tail). 
Table 2: Test of hypotheses

\begin{tabular}{|c|c|c|c|c|c|c|c|}
\hline DV: NPP & Model 1 & Model 2 & Model 3 & Model 4 & Model 5 & Model 6 & Model 7 \\
\hline \multicolumn{8}{|l|}{ Main Variables Effects } \\
\hline Firm age & 0.04 & -0.10 & -0.05 & -0.10 & -0.05 & -0.10 & -0.05 \\
\hline Firm size & -0.10 & -0.11 & -0.10 & -0.09 & -0.09 & -0.09 & -0.08 \\
\hline Technological uncertainty & -0.08 & -0.14 & -0.14 & -0.14 & -0.14 & $-0.15^{\dagger}$ & $-0.15^{\dagger}$ \\
\hline Market uncertainty & 0.03 & -0.01 & 0.03 & -0.02 & 0.06 & -0.03 & 0.06 \\
\hline Exploratory product innovation & & $0.42^{* *}$ & $0.40^{* *}$ & $0.41^{* *}$ & $0.37^{* *}$ & $0.41^{* *}$ & $0.37^{* *}$ \\
\hline Exploitative product innovation & & 0.05 & -0.06 & 0.02 & -0.05 & 0.05 & -0.05 \\
\hline Slack resources & & $0.18^{*}$ & $0.14^{\dagger}$ & $0.17^{*}$ & $0.16^{*}$ & $0.16^{*}$ & $0.15^{\dagger}$ \\
\hline Social networking capability & & 0.06 & -0.03 & 0.06 & -0.03 & 0.08 & -0.03 \\
\hline \multicolumn{8}{|l|}{ Ambidexterity } \\
\hline H1a: Balanced ambidexterity (BD) & & & $0.45^{\text {** }}$ & & $0.40^{* *}$ & & $0.38^{* *}$ \\
\hline H1b: Combined ambidexterity (CD) & & & & $0.20^{*}$ & & $0.18^{*}$ & 0.09 \\
\hline \multicolumn{8}{|l|}{ Interactions } \\
\hline H2a: BD $\times$ Slack resources & & & & & -0.02 & & 0.02 \\
\hline H3a: $\mathrm{BD} \times$ Social networking capability & & & & & $-0.17^{*}$ & & $-0.16^{*}$ \\
\hline H2b: $\mathrm{CD} \times$ Slack resources & & & & & & $0.21^{*}$ & $0.17^{*}$ \\
\hline H3b: $\mathrm{CD} \times$ Social networking capability & & & & & & $0.17^{*}$ & $0.16^{\dagger}$ \\
\hline $\mathbf{R}^{2}$ & 0.03 & 0.30 & 0.51 & 0.34 & 0.53 & 0.40 & 0.55 \\
\hline
\end{tabular}




\section{Figure 1: Theoretical Framework}

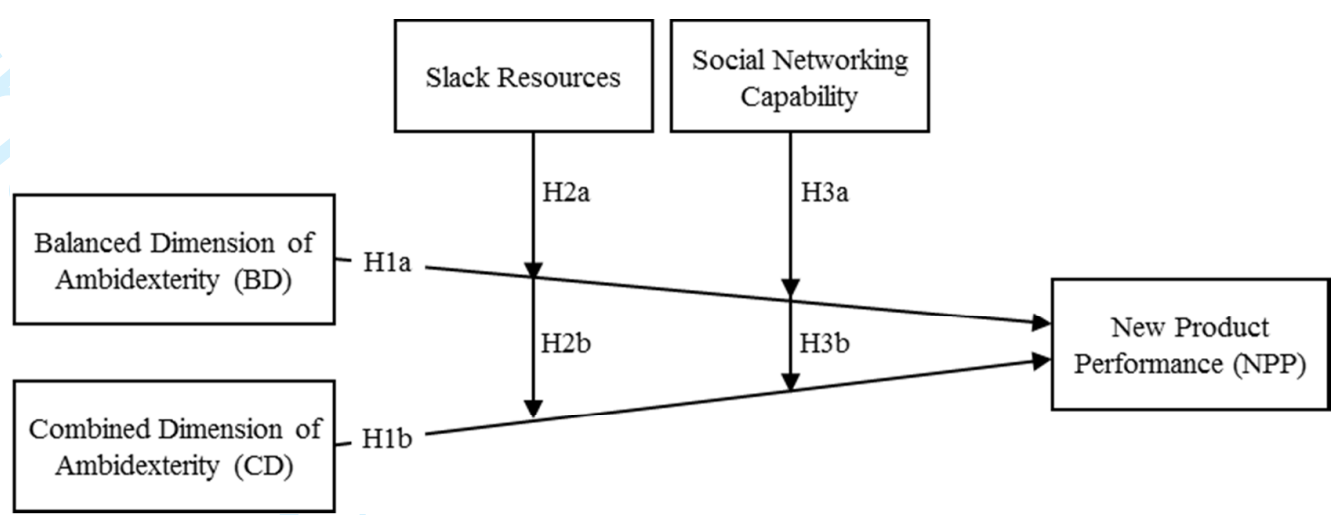




\section{Figure 2: Interactions}

A) Interaction between BD and slack resources (SL)

B) Interaction between CD and SL
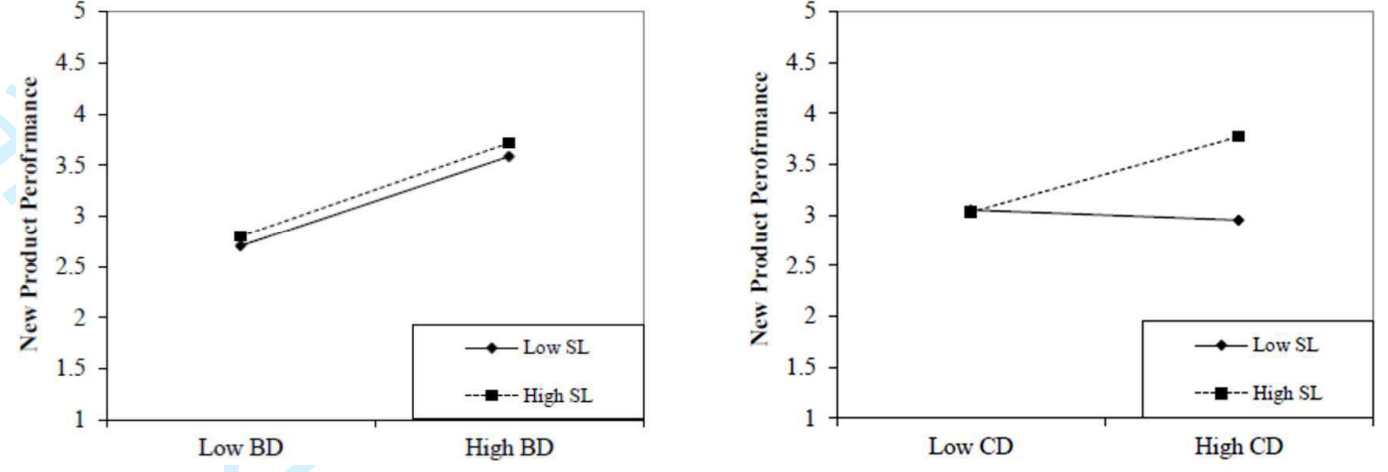

C) Interaction between BD and Social networking

D) Interaction between $\mathrm{CD}$ and $\mathrm{SNC}$
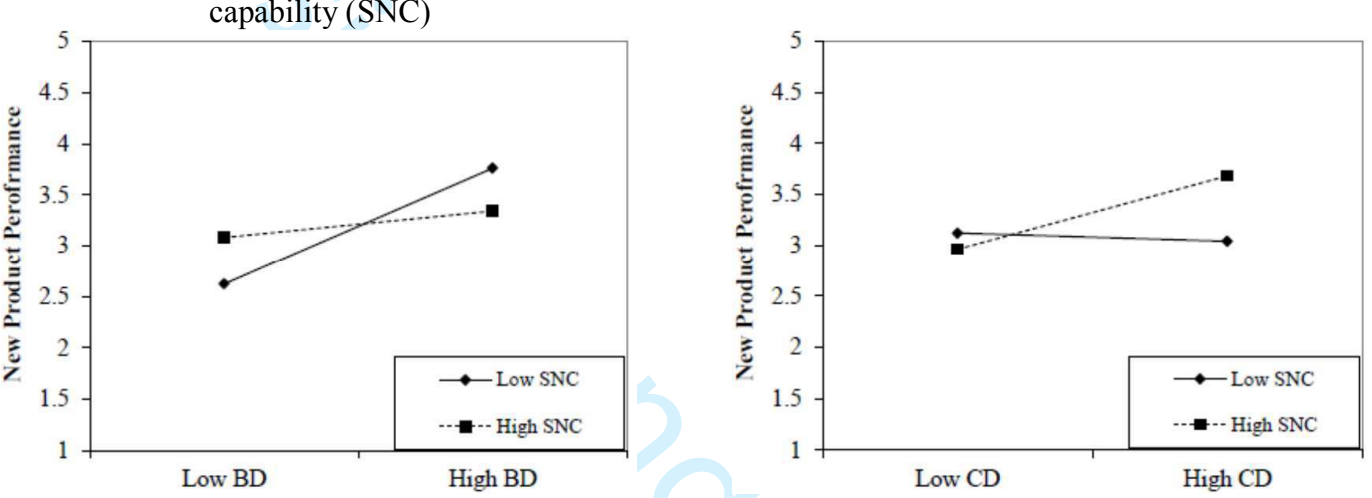

30

31

32

33

34

35

36

37

38

39

40

41

42

43

44

45

46

47

48

49

50

51

52

53

54

55

56

57 